\title{
Parasitization and Identification of The Red Guava Fruit Fly Parasitoids in The Deli Serdang District
}

\author{
DOI: 10.18196/pt.2019.104.137-140
}

\author{
Putri Mustika Sari ${ }^{1 *}$, Darma Bakti ${ }^{2}$, Lisdayani ${ }^{1}$ \\ ${ }^{1}$ Department of Agrotechnology, Faculty of Agriculture, Universitas Alwashliyah Medan, \\ Jl. Sisingamangaraja No $10 \mathrm{Km}$ 5,5 Medan, Sumatera Utara 20147, Indonesia \\ ${ }^{2}$ Department of Agrotechnology, Faculty of Agriculture, Universitas Sumatera Utara, \\ Jl. Dr. A. Sofian No. 3, Padang Bulan Medan, Sumatera Utara 20155, Indonesia \\ *Corresponding author, email: h0lm3s44@ymail.com
}

\begin{abstract}
Deli Serdang District is one of the regions producing red guava fruit in Sumatra Utara. Cultivation of fruit trees is never separated from pest disorders, which can cause a decrease in the quality and quantity of fruit. Then proper control is needed so that it can maintain the balance of insect populations in the field. This study aims to determine the type of parasitoid and parasitoid parasitic level in red guava cropss. Identification morphology of parasitoid's fruit flies rearing from red guava fruit that had been attacked by fruit flies was taken from several locations of red guava crops in Deli Serdang District. Two species of parasitoid Psytalia sp. the parasitic fruit fly in the red guava crop. The parasitoids that have been found then identified at LIPI, Cibinong, Bogor morphologically has many similarities with Psytalia walker and Psytalia walkeri so that identification of species is only made close to the morphology of the species. Only in two locations were found parasitoid's rearing from infected fruit, namely Parasitization rate of 6.9\% in Sei Beras Sekata village, and Kolam village of $3.6 \%$.
\end{abstract}

Keywords: Identification; Morphology; Parasitization; Psytalia sp.

\section{ABSTRAK}

Kabupaten Deli Serdang merupakan salah satu wilayah penghasil buah jambu biji merah di Sumatera Utara. Budidaya tanaman buah tidak pernah lepas dari gangguan hama, yang dapat menyebabkan penurunan kualitas dan kuantitas buah. Maka perlu dilakukan pengendalian yang tepat sehingga dapat menjaga keseimbangan populasi serangga di lapangan. Penelitian ini bertujuan mengetahui jenis parasitoid dan daya Parasitisasi parasitoid di pertanaman jambu biji merah. Identifikasi morfologi parasitoid lalat buah hasil rearing buah jambu biji merah yang telah terserang lalat buah diambil dari beberapa lokasi pertanaman jambu biji merah di Kabupaten Deli Serdang. Ditemukan dua spesies parasitoid Psytalia sp. yang memparasit lalat buah di pertanaman jambu biji merah. Parasitoid yang telah ditemukan kemudian diidentifikasi di LIPI, Cibinong, Bogor secara morfologi memiliki banyak kesamaan dengan Psytalia walker dan Psytalia walkeri sehingga untuk identifikasi spesies hanya dibuat mendekati morfologi spesies tersebut. Hanya pada dua lokasi ditemukan parasitoid hasil rearing dari buah yang terserang, yakni tingkat Parasitisasi sebesar 6.9\% di desa Sei Beras Sekata, dan desa Kolam sebesar 3.6\%.

Kata Kunci: Identifikasi; Morfologi; Parasitisasi; Psytalia sp.

\section{INTRODUCTION}

Fruit farming is inseparable from the Plant Disturbing organisms, which can reduce production and become a barrier to trade between countries (Kardinan et al., 2009). One of them is fruit fly (Bactrocera sp.) which is a concern in the world because it is an important pest in the fruit. This pest has also been a problem in fruit commodities in Indonesia (Suputa et al., 2007).

The productivity of red guava in Deli Serdang District has reportedly decreased since 2010, red guava production amounted to 35,261 fell to 12,661 tons in 2014 (Badan Pusat Statistik, 2016). Reduced productivity of red guava one of which can be caused by fruit fly attacks that cause dam-

age to fruit and reduce the quality and quantity of yields (Amin, 2015).

All ways to control fruit flies have been done, among others, fruit wrapped, biological control, pesticide use, etc. (Dhillon et al., 2005). The use of pesticides has proven effective but leaves chemical residues, therefore it is necessary to control environmentally friendly and have been proven effective namely the use of methyl eugenol as an attractant (Vargas, 2007). Biological control by utilizing the role of parasitoids from the family Branconidae (Hymenoptera), namely Fopius sp. and Biosteres sp. also able to suppress fruit fly populations in the field (Siwi et al., 2006). 
Drew \& Romig (2012) states that identification of insect species is very important, because some groups of insect taxa have almost the same variation in morphological characters. For example, the difference in body shape of insects with one another between B. carambolae and B. papayae is due to the genetic relationship closeness so that from the shape of the abdomen and the wing pattern looks almost the same, in other species the direct difference can be seen only from the pattern of the wings (Pramudi et al., 2013). Study about fruit fly parasitoids in Deli Serdang District is urgently needed so that control can be carried out using parasitoids that are suitable for the target pest.

\section{MATERIALS AND METHODS}

Collecting Fruit Attacked

We collected 5 attacked fruits by purposive random sampling as much as $4 \mathrm{x}$ with an interval of 2 weeks at each sample location. The fruit is placed into a jar that has been filled with sand.

\section{Rearing of Fruit Fly Parasitoid}

To get fruit flies pupa, the sand was sifted every two days for 2 weeks. The collected fruit flies were placed in another plastic container then use gauze as a cover. Fruit flies Imago and parasitoids were seen given feed in the form of a solution of honey until the imago was 3 days old, after enough age the imago was turned off and stored in bottles that had been filled with 70\% alcohol and identified.

\section{Morphological Identification}

The parasitoid that has been found was identified morphologically including caput, thorax, wings, abdomen, using a microscope and assisted with the book identification of Hymenoptera parasitoid, entitled Hymenoptera of the World An Identification Guide To Families (Goulet \& Huber, 1993), in the Research Center Laboratory Biology, LIPI Cibinong Bogor.

\section{Parasitic Level}

Calculation of the level of Parasitization of each parasitoid associated with the red guava crop, using the formula (Buchori et al., 2010).

$$
\mathrm{TP}=\frac{\sum \mathrm{A}}{\sum \mathrm{B}+\Sigma \mathrm{A}} \mathrm{X} 100 \%
$$

Remark:

TP $=$ Parasitic level

$\mathrm{A}=$ The number of parasitoids that appear

$B=$ The number of fruit fly imago

\section{RESULTS AND DISCUSSION}

The dentification of parasitoids at LIPI were obtained 2 species, which were Psytalia sp. near walker and Psytalia sp. near walkeri found in fruit fly imago at red guava crops of the Sei Beras Kata village and the Kolam village, shown in Table 1.

Morphology of Psytalia sp. near walker, the antenna has 52 segments. It has a medial dark 2RS front wing, anterior-posterior infumate band through the middle of the front wing. The abdoTable 1. Morphology of Parasitoid Fruit Flies

\begin{tabular}{lll}
\hline Character & Caput & Wings \\
Psytalia sp. \\
near walker \\
Psytalia sp. \\
near walkeri
\end{tabular}


men is oval with black lines that are not entirely full. the body is brownish yellow, the legs are brown.

Morphology of Psytalia sp. near walkeri is the Abdomen with full black lines. The m-cu and subdiscal distal front wing arches are enlarged. The antenna has 50 vertebrae, brownish-yellow bodies, there is an occipital carina that extends the height of the back more than the height of the head.

In Table 2, the effectiveness of the parasitoid in controlling fruit flies in these two locations can be measured by parasitic level, ie in the village of Sei Beras Sekata has a parasitic level of $6.9 \%$, and the village of Kolam is $3.6 \%$. Based on the parasitic level, it can be assessed the ability of natural enemies in regulating the balance of fruit fly populations at both locations is very small. One of the low parasitic level is thought to be due to the use of insecticides in the field by farmers and how to cultivate that is not in accordance with environmental rules (e.g. too tight spacing), thus adversely affecting the presence and parasitic level of parasitoid in the field. According to Herlinda (2007) and Berryman (1981), factors that influence the development of parasitoids are (a) the amount of food, food suitability, nutrient content, appropriate water content and host plants suitable for growth and development, (b) temperature, good humidity, light and aeration for mass breeding, (c) the extent to which pest control measures have been carried out by manipulation of host plants, crop rotation or control with pesticides, $(\mathrm{d})$ insects are able to create resistance naturally so that insects are able to adapt to physiological changes in the host or food so that the insect is able to maintain its life.

Table 2. Parasitoid Parasitic Level

\begin{tabular}{lll}
\hline Locations & Kolam Village & Sei Beras Sekata Village \\
\hline Number of fruit & 20 & 20 \\
Number of fruit fly & 27 & 54 \\
Number of parasitoid & 1 & 4 \\
Parasitic level & $3.6 \%$ & $6.9 \%$ \\
\hline
\end{tabular}

From Table 2, it can be seen the difference in level parasitic in the two locations, namely in the village of Sei Beras Sekata (6.9\%) having a higher parasitic power level than in the village of Kolam (3.6\%), this is presumably because of the red guava crops in Sei village Sei Beras Sekata is next to the corn crop land, where it is known that the pollen of the corn plant can be a source of additional food for parasitoids. According to Russell (1989) states that higher flora diversity provides more niches and habitat for insect species, and according to Herlinda (2005) that Tetrastichus and O. sokolowskii are only found in the rainy season because in that season the caisin crop area is wider and species other plants that live are also more diverse than in the dry season.

\section{CONCLUSION}

The type of natural enemy found in this study was very low, only 2 species of parasitoid were found. This amount is certainly less effective in controlling fruit flies in the field. The results of the identification morphologically parasitoid namely Psytalia sp. near walker and Psytalia sp. near walkeri came from Sei Beras Kata village and Kolam village, with the highest parasitoid parasitic level of $6.9 \%$ found in Sei Beras Sekata village.

\section{REFERENCES}

Amin, N.N.A. 2015. Perilaku Oviposisi lalat buah B. papyae dan B. carambolae pada tingkat kematangan buah jambu biji. Skripsi. IPB, Bogor.

[BPS] Badan Pusat Statistik. 2016. Produksi tanaman buah-buahan di kabupaten Deli Serdang [Internet]. Tersedia pada: http:// www.bps.go.id.

Berryman, A.A. 1981. Population System. New York: A General Press.

Buchori, et al. 2010. Species Distribution of Trichogramma and Trichogrammatoidea Genus in Java. J. Issaas, 16(1): 83-96.

Dhillon, M. K., R. Singh, J. S. Naresh, \& H. C. Sharma. 2005. The Melon Fruit Fly, Bactrocera cucurbitae: A Review of Its Biology and Management. J. Insect Sci. 5:1-16.

Drew, R. \& Romig M. C. 2012. Quarantine surveillance for tropical fruit flies (Tephritidae: Dacinae). Fruit Flies of Indonesia: Their Identification, Pest Status and Pest Management. Griffith University Brisbane (AU): ICMPFF. hlm 7-20. 
Planta Tropika: Jurnal Agrosains (Journal of Agro Science) Vol. 7 No. 2 / August 2019

Goulet, H., \& J.T. Huber. 1993. Hymenoptera of the world: an identification guide to families. Centre for Land and Biological Resources Research Ottawa, Ontario. Research Branch, Agriculture Canada.

Herlinda, S. 2005. Parasitoid dan Parasitisasi Plutella xylostella (L.) (Lepidoptera: Yponomeutidae) di Sumatera Selatan. J. hayati. 12(4) : 151-156.

Herlinda, S., Mayasari R., Adam T., \& Pujiastuti Y. 2007. Populasi dan serangan lalat buah Bactrocera dorsalis (Hendel) (Diptera: Tephritidae) serta potensi parasitoid pada pertanaman cabai (Capsicum annuum L.). Seminar Nasional dan Kongres IImu Pengetahuan Wilayah Barat. (ID). hlm:1-13.

Kardinan, A., Bintoro, M. H., Syakir, M. \& Amin, A.A. 2009. Penggunaan Selasih Dalam Pengendalian Hama Lalat Buah Pada Mangga. Institute Bogor. Bogor. J. Perlindungan Tanaman Indonesia. 15(3):101-109.

Pramudi, M.I., R.D. Puspitarini, \& B.T. Rahardjo. 2013. Keanekaragaman dan Kekerabatan Lalat Buah (Diptera: Tephritidae) Di Kalimantan Selatan Berdasarkan Karakter Morfologi dan Molekular (RAPD-PCR dan Sekuensing DNA). J. HPT Tropika. 13(2):191 - 202.

Russell EP. 1989. Enemies hypothesis: A review of the effect of vegetational diversity on predatory insect and parasitoids. J. Environ Entomol 18:590-599.

Siwi, S.S., Hidayat P., \& Suputa. 2006. Taksonomi dan Bioekologi Lalat Buah Penting di Indonesia. Bogor: Kerjasama Balai Besar Penelitian dan Pengembangan Bioteknologi dan Sumberdaya Genetik Pertanian dengan Departement of Agriculture, Fisheries and Forestry Australia

Suputa, E., Martono, Z., Hussein, \& A.T. Arminudin. 2007. Preliminary study: Odontoponera denticulate as a potential predator to reduce true fruit fly population in Jogjakarta. J. IImu-IImu Pertanian. 3(3):351-356.

Vargas, R., 2007. Local research, but everyone watching. Agriculture Research Service-Hawaii Area Wide Fruit fly Control Program, 4 pp. http://www.findarticles.com/p/articles/mi_m3741/ is_2_52/ai_113457520. 